\title{
Article \\ Compressive Properties of Green Velvet Material Used in Mattress Bedding
}

\author{
Qingqing Liu ${ }^{1,2}$, Yanting Gu ${ }^{1,2, *}$, Wei $\mathrm{Xu}^{1,2, *}$, Tao Lu ${ }^{3}$, Wenjun $\mathrm{Li}^{4}$ and Haibin Fan ${ }^{4}$ \\ 1 Jiangsu Co-Innovation Center of Efficient Processing and Utilization of Forest Resources, Nanjing Forestry \\ University, Nanjing 210037, China; 0321lqq@njfu.edu.cn \\ 2 College of Furnishings and Industrial Design, Nanjing Forestry University, Nanjing 210037, China \\ 3 Nanjing Kingrate Kylin Home Collection Co., Ltd., Nanjing 210000, China; 13305170395@126.com \\ 4 Suzhou Kingcharm New Materials Corp., Suzhou 215000, China; Lwjs66@126.com (W.L.); \\ csfhb@kingcharmcn.com (H.F.) \\ * Correspondence: guyanting@njfu.edu.cn (Y.G.); xuwei@njfu.edu.cn (W.X.); Tel.: +86-025-8542-7528 (Y.G.); \\ $+86-025-8542-7459$ (W.X.)
}

check for updates

Citation: Liu, Q.; Gu, Y.; Xu, W.; Lu, T.; Li, W.; Fan, H. Compressive Properties of Green Velvet Material Used in Mattress Bedding. Appl. Sci. 2021, 11, 11159. https://doi.org/ 10.3390/app112311159

Academic Editor: Ana M. Camacho

Received: 19 October 2021

Accepted: 14 November 2021

Published: 24 November 2021

Publisher's Note: MDPI stays neutral with regard to jurisdictional claims in published maps and institutional affiliations.

Copyright: (c) 2021 by the authors. Licensee MDPI, Basel, Switzerland. This article is an open access article distributed under the terms and conditions of the Creative Commons Attribution (CC BY) license (https:/ / creativecommons.org/licenses/by/ $4.0 /)$.

\begin{abstract}
With the increasing awareness of environmental protection, Green Velvet Material (PLON), a renewable and environmentally friendly material, has been widely applied to mattresses. In order to improve the compressive properties of PLON, a series of experiments were carried out with special attention given to the compression deformation characteristics, support performance of the PLON blocks and its effective application in mattress products. The results are: (1) Average slopes of the load-deformation curves' two phases are represented by $\mathrm{K} 1$ and $\mathrm{K} 2$, respectively. $\mathrm{K} 1$ is more sensitive to density changes that range from $30 \mathrm{~kg} / \mathrm{m}^{3}$ to $50 \mathrm{~kg} / \mathrm{m}^{3}$, while $\mathrm{K} 2$ is sensitive to density changes that range from $20 \mathrm{~kg} / \mathrm{m}^{3}$ to $50 \mathrm{~kg} / \mathrm{m}^{3}$. Their values increase with the rise of density; (2) $25 \%$ IFD, $40 \%$ IFD, $65 \%$ IFD, SF and IHF values are sensitive to density changes and they significantly increase with the rise of density. PLON blocks have excellent supporting properties and are considered to be comfortable according to American FPF Test Standard (ASTM-D3574-B1) when used in mattress bedding; (3) a PLON block density of $30 \mathrm{~kg} / \mathrm{m}^{3}$ is preferentially selected for the softer type of mattress, while a PLON block density of $40 \mathrm{~kg} / \mathrm{m}^{3}$ is preferentially selected for the harder type of mattress. The compression deformation characteristics and support performance of the PLON blocks were analyzed and the effective application of PLON in mattress products was explored through the above research.
\end{abstract}

Keywords: mattress; indentation hardness; support performance; compressive properties

\section{Introduction}

The bedding layer is a buffer layer between the quilting layer and the spring layer of a mattress, which can protect the spring core and make the pressure of the spring layer more balanced [1,2]. Flexible Polyurethane Foam (FPF) is mainly used for mattress bedding layers, providing suitable support for the human body. The main components of FPF are polyol (ether), TDI, and foaming agent [3]. However, the FPF is non-renewable and difficult to degrade. CFC foaming agents will be formed by waste polyurethane foam. Ozone layer substances will be depleted [4,5]. Latex is also used in the mattress bedding layer, which is divided into natural latex and synthetic latex. Natural and synthetic latex are both used in the mattress bedding layer. It is anti-mite and antibacterial with characteristics of good elasticity, air permeability and decomposability. However, the output of natural latex is low and resources are limited. The polyurethane added in synthetic latex is difficult to degrade [6,7]. Natural plant materials, such as palm silk, mountain brown silk, bamboo silk, hemp fiber, and loofah, have been applied to the mattress bedding layer. They have excellent properties such as abrasion resistance and resistance to fading. However, the mattresses made of these materials have disadvantages of high hardness, low resilience, 
poor comfort, and are not easy to transport. What is more, the palm mattresses are prone to insects and mildew [8,9].

Green Velvet Material (later referred to as PLON) is a new green fiber material, which is made from semi-gloss low-viscosity polyester chips (later referred to as PET) and polybutylene terephthalate chips (later referred to as PBT) as raw materials. Its components are aromatic polyester, recycled polyester, polylactic acid, and so forth. These components are renewable, non-toxic and non-irritating gas. Compared with polyurethane FPF, latex, loofah and other materials, PLON is renewable, soft and has good resilience, strong deformation resistance, low elastic attenuation and good air permeability. The resilience of $20 \mathrm{~kg} / \mathrm{m}^{3} \mathrm{FPF}$ is $50 \%$ while the resilience of $20 \mathrm{~kg} / \mathrm{m}^{3}$ PLON is $62 \%$; the resilience of $30 \mathrm{~kg} / \mathrm{m}^{3} \mathrm{FPF}$ is $43 \%$ while the resilience of $30 \mathrm{~kg} / \mathrm{m}^{3} \mathrm{PLON}$ is $76 \%$ [10,11]. It is indicated that PLON is a potential material used in mattress bedding.

Compressive performances of mattress bedding have an important influence on the quality and comfort of mattress, mainly including indentation hardness, resilience performance, permanent compression deformation and so forth $[12,13]$. Special attention related to the compressive performances of FPF was focused by $\mathrm{Hu}$ et al. Their works indicated that density has a significant influence on a cushion's performance. Spring constant is used to characterize the compressive properties of seat foundation by Hu et al. [14]. That density and a combination of FPF have a significant impact on sitting comfort was found by $\mathrm{Xu}$ et al. [15]. The comfortableness of cushions depends on FPF density, indentation hardness and other related factors. Huang et al. [16] adopted indicators, such as IFD, SF, MIF and IHF and so forth, to quantitatively analyze the indentation hardness and support performance of the FPF cushion. It was showed that the SF and IHF values of the sponge are related to the indentation hardness and type of FPF. Type, density and thickness have a significant influence on mattress's hardness were found by Yu et al. [17]. The hardness of FPF increases as density increases. That density has a significant effect on the compressive strength and platform stress of the columnar loofah was found by Chen et al. [18]. Twentyfive percent IFD, sixty-five percent IFD and SF are used to evaluate the load-deflection curves of rattan seat foundation specimens by $\mathrm{Gu}$ et al. [19].

Until now, there is a lack of special research on the compressive properties of PLON materials used for the bedding layer of a mattress. This research aims to evaluate the static compressive properties of PLON materials. Specific objectives include giving full play to the advantages of this new fiber; and to explore the effective and reasonable application of the fiber in mattress products. Cushions made of PLON act as the main raw material. They were used as the research object, combined with comparative samples such as FPF, ELK cotton, latex, and so forth. Relevant compression performance and resilience performance test analysis and research were carried out to provides basic data for making new PLON fiber mattress with good comfort and moderate hardness: (1) Stiffness and compression deformation characteristics of the PLON blocks were analyzed through the load-deformation curve; (2) Support performance and surface softness of the PLON blocks were evaluated through the support performance index test

\section{Materials and Methods}

\subsection{Materials}

The specific processing methods of PLON fiber are (Figure 1): (1) The raw materials were put into the drum for $10 \mathrm{~h}$ to dry. They were then sent to the screw for heating, where the mixing ratio of PET and PBT chips is 3:7 5:5; (2) raw materials heated and filtered were fed into the spinneret. The fiber filaments ejected from the spinneret were bundled and drawn through the bundling frame, forming multiple strands from one strand. Then it was oiled in an oil tank and was heated by steam at 100 degrees in a drying room. The curling machine curled the shape and can form a certain curl according to the needs. In addition, it was baked in an oven at 120 degrees for $30 \mathrm{~min}$. The formed PLON fiber can be cut into a certain size with a warp cutting machine as needed; (3) 35\% elastic low melting point composite fiber (later referred to as EJQ), 40\% PLON, 10\% 3D hollow fiber and 15\% low 
melting point composite fiber (later referred to as ES) were used to make PLON blocks by carded web. The carded web is used to straighten the messy single fibers through a carding machine into a parallel state. Then the parallel straight single fibers were condensed into a net or randomly arranged into a net [20-22].

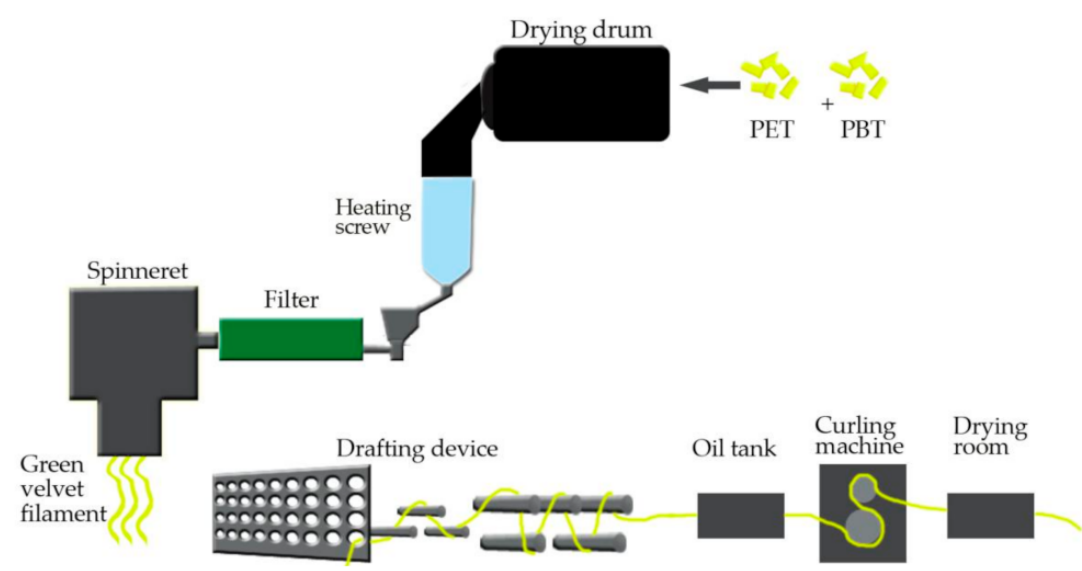

Figure 1. Schematic diagram of PLON fiber production.

PLON cushions with different densities were selected for the indentation hardness test, which were provided by Jinquan New Materials Co., Ltd. (Suzhou, China) (Figures 2 and 3). Four levels of density were selected: $20 \mathrm{~kg} / \mathrm{m}^{3}, 30 \mathrm{~kg} / \mathrm{m}^{3}, 40 \mathrm{~kg} / \mathrm{m}^{3}, 50 \mathrm{~kg} / \mathrm{m}^{3}$. The size of the sample was $380 \times 380 \times 100 \mathrm{~mm}$. The repetition amount of each sample was three pieces. All samples were tested in an environment with a temperature of $23 \pm 2{ }^{\circ} \mathrm{C}$ and a humidity of $45 \sim 55 \%$.

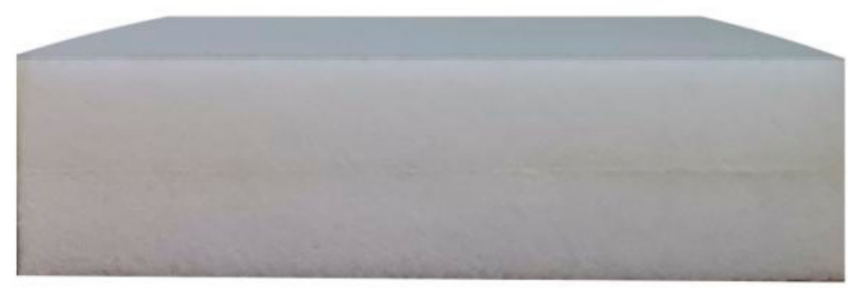

Figure 2. Physical appearance of evaluated PLON blocks.

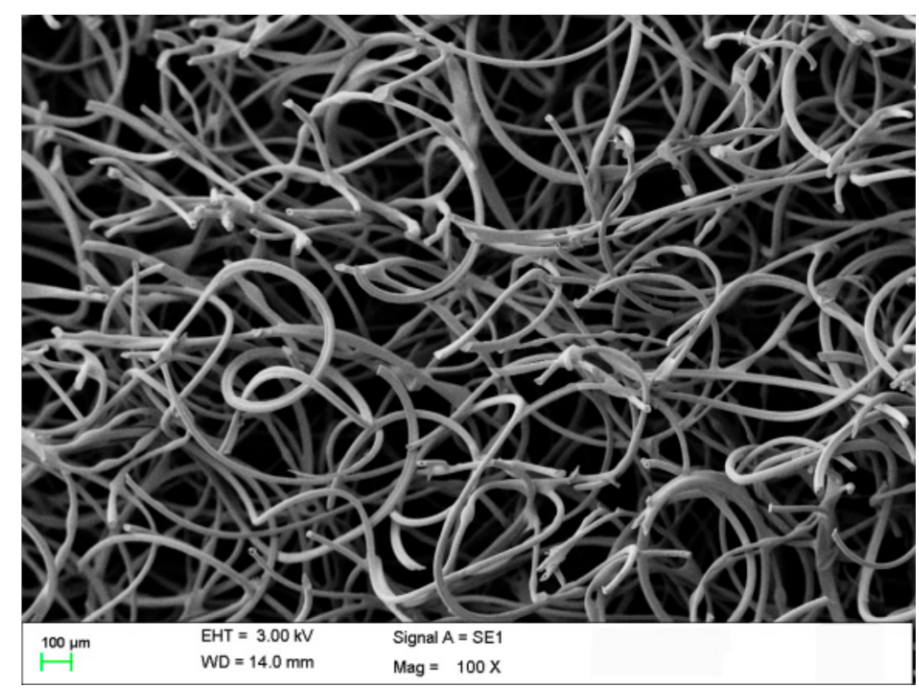

Figure 3. SEM images of typical PLON blocks. 


\subsection{Methods}

An SLFL-100KN universal testing machine provided by Shimadzu Co., Ltd. Tokyo, (Japan) was used as the indentation hardness test. This experiment follows the American FPF Test Standard (ASTM-D3574-B1) [23]. The diameter of the circular loading head used in the test was $200 \mathrm{~mm}$. Test speed was $100 \mathrm{~mm} / \mathrm{min}$. Test pieces were placed in the center of the test bench. Loading head was lowered and loaded at a specified speed. When the loading head was lowered to $85 \%$ of the thickness of the test piece, it would be unloaded. The vertical loading method was shown in the Figure 4.

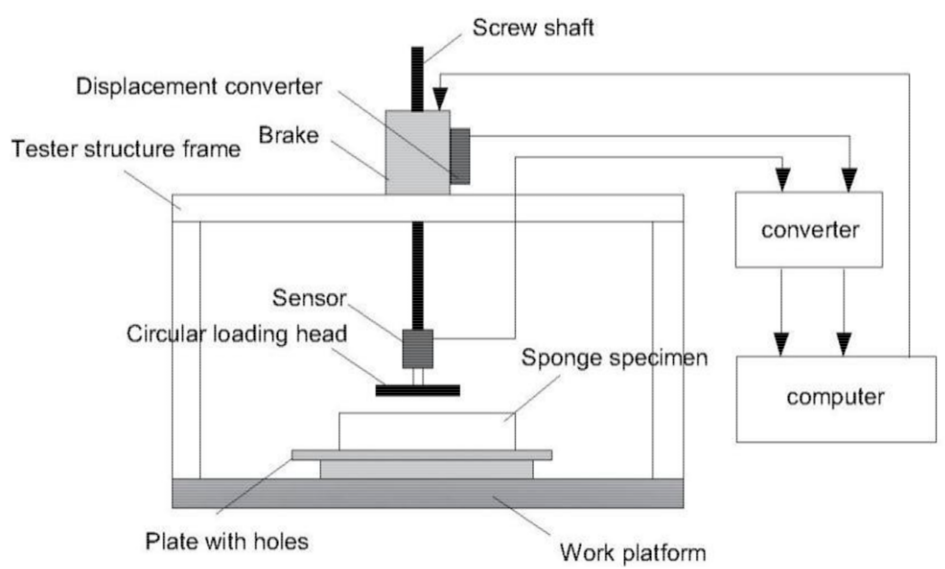

Figure 4. Mechanical test system diagram.

\section{Results}

\subsection{Load-Deformation Curve}

Figure 5 showed a typical load-deformation curve of the tested PLON blocks. The two typical phases, including Phase I (the first linear region) and Phase II (the densification region that exhibited nonlinearity behavior with a sharp increase in the material's stiffness), could be identified for all the load-deformation curves of the evaluated PLON materials. The PLON block has its deformation in the linear elasticity region, accounting for $30 \%$ of the entire deformation (as shown in Figures 5 and 6). Compared with PLON, the loaddeformation curves of FPF and loofah blocks have three typical phases including Phase I (the first linear region), Phase II (the second linear portion, which belongs to the plateau region and exhibits reduced stiffness compared to the stiffness of Phase I) and Phase III (the densification region) [24]. The load-deformation curves of coir and latex exhibited two typical phases similar to those of PLON: linear elasticity and densification [25].

Figure 6 showed typical load-deformation curves of the tested four PLON blocks with different densities. The average slopes of the two phases are respectively represented by $\mathrm{K} 1$ and K2. The least square linear regression technique is used to derive these slope values. The PLON block has its deformation in the linear elasticity region, accounting for $30 \%$ of the entire deformation (as shown in Figures 5 and 6). Table 1 summarized the ANOVA results obtained from the GLM procedure performed for each of the three evaluated properties of the PLON cushion. It was indicated that the main effects of PLON blocks with different densities on $\mathrm{K} 1$ and $\mathrm{K} 2$ values are statistically significant at the $5 \%$ significance level. Table 2 summarized the means of these average slope values and their comparisons were performed using the LSD multiple comparisons procedure. The mean comparison results indicated that the high-density PLON materials used in this experiment had significantly higher average slope values than the low density ones for K2, as was shown in Table 2. There were no significant differences among PLON blocks with densities of $20 \mathrm{~kg} / \mathrm{m}^{3}$ and $30 \mathrm{~kg} / \mathrm{m}^{3}$, but there were significant differences among PLON blocks with densities of $30 \mathrm{~kg} / \mathrm{m}^{3}, 40 \mathrm{~kg} / \mathrm{m}^{3}$ and $50 \mathrm{~kg} / \mathrm{m}^{3}$ for K1, as was shown in Table 2 . 


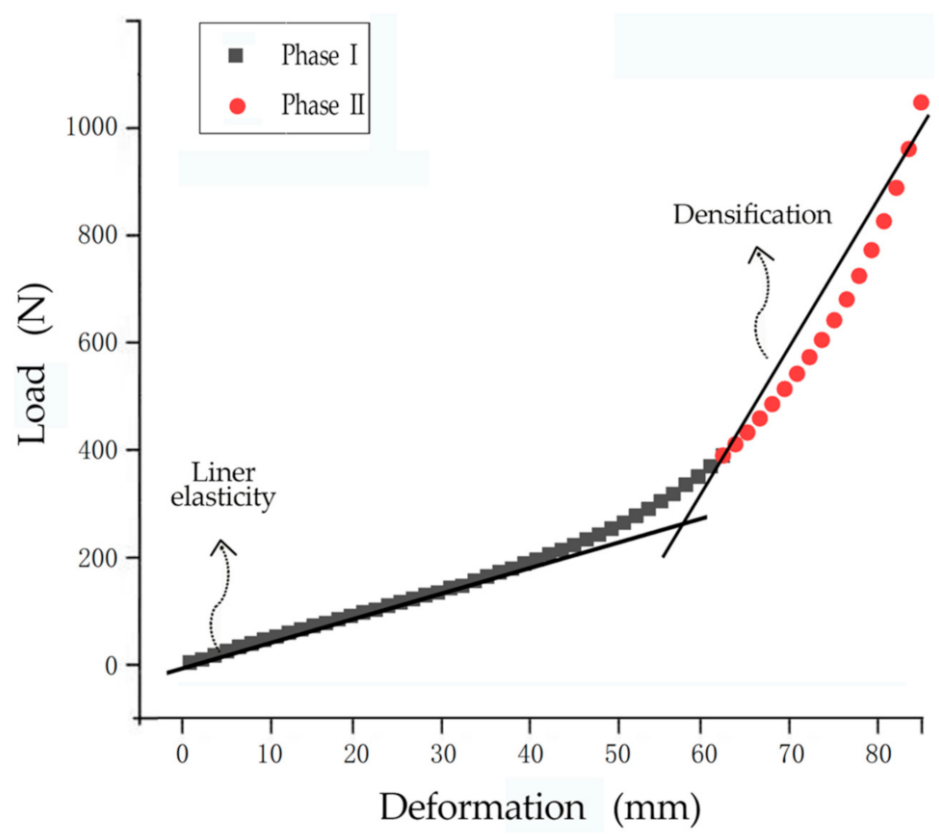

Figure 5. A typical load-deformation curve of the tested PLON block.
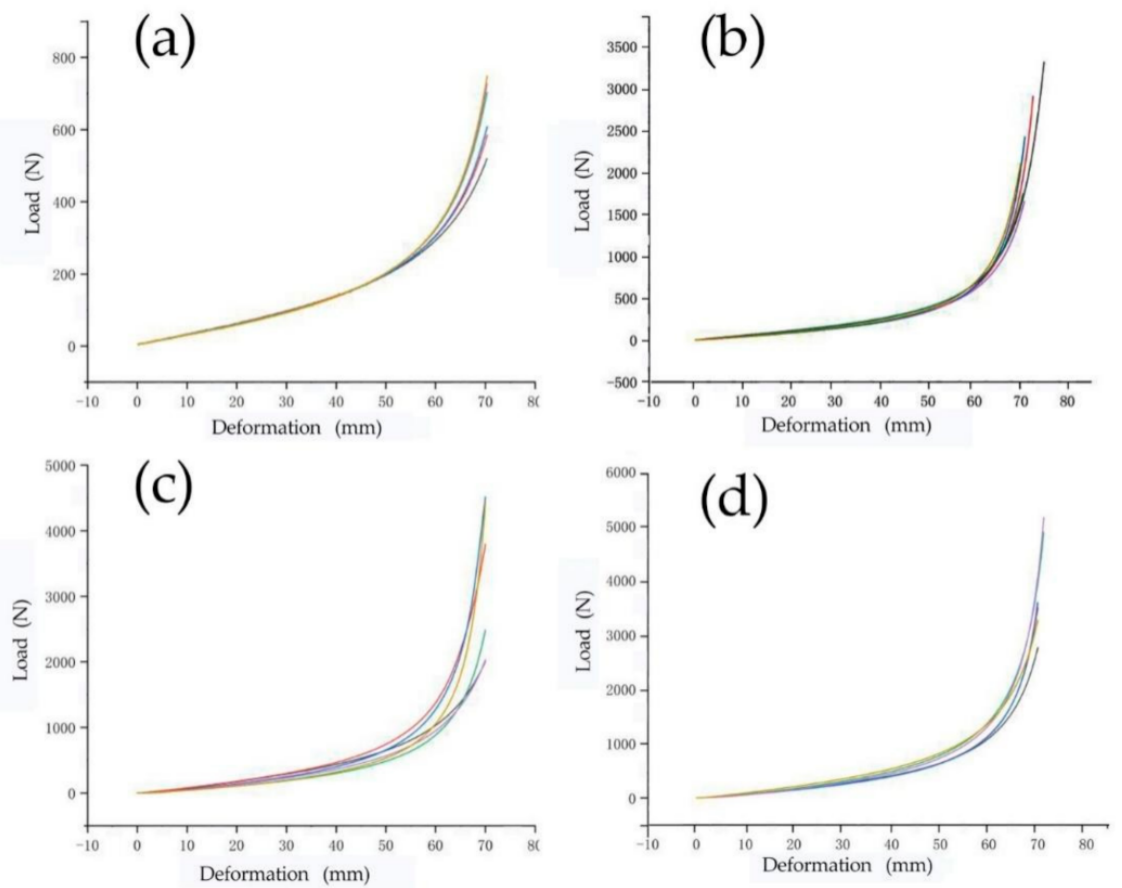

Figure 6. Typical load-deformation curve of the tested PLON block with different densities: (a) $20 \mathrm{~kg} / \mathrm{m}^{3}$ PLON block's typical load-deformation curve, (b) $30 \mathrm{~kg} / \mathrm{m}^{3}$ PLON block's typical load-deformation curve, (c) $40 \mathrm{~kg} / \mathrm{m}^{3}$ PLON block's typical load-deformation curve, (d) $50 \mathrm{~kg} / \mathrm{m}^{3}$ PLON block's typical load-deformation curve.

Table 1. ANOVA results performed on three factors.

\begin{tabular}{cccccc}
\hline \multirow{2}{*}{ Source } & \multicolumn{3}{c}{ K1 } & \multicolumn{2}{c}{ K2 } \\
\cline { 2 - 5 } & F Value & & $\boldsymbol{p}$ Value & F Value & $p$ Value \\
\hline PLON & 357.03 & $<0.0001$ & 31.54 & $<0.0001$ \\
\hline
\end{tabular}


Table 2. Mean K Values of the four PLON Densities Evaluated in this Study.

\begin{tabular}{|c|c|c|c|c|c|}
\hline \multirow{2}{*}{$\begin{array}{l}\text { Spring } \\
\text { Constant }\end{array}$} & \multicolumn{4}{|c|}{ PLON Density $\left(\mathrm{kg} / \mathrm{m}^{3}\right)$} & \multirow{2}{*}{ LSD Values } \\
\hline & $20 \mathrm{~kg} / \mathrm{m}^{3}$ & $30 \mathrm{~kg} / \mathrm{m}^{3}$ & $40 \mathrm{~kg} / \mathrm{m}^{3}$ & $50 \mathrm{~kg} / \mathrm{m}^{3}$ & \\
\hline K1 & 4.12 (7) C & 5.11 (9) C & 7.67 (21) B & $10.69(21) \mathrm{A}$ & 1.21 \\
\hline K2 & 35.18 (17) D & 135.30 (28) C & 187.95 (41) B & 262.04 (37) A & 52.43 \\
\hline
\end{tabular}

Note: Values in parentheses are the coefficients of variation (percentages).

The $\mathrm{K} 1$ value insignificantly increased when the density changed from $20 \mathrm{~kg} / \mathrm{m}^{3}$ to $30 \mathrm{~kg} / \mathrm{m}^{3}$, indicating that the K1 value was not sensitive to the change of low density. K1 values were more sensitive to density changes that range from $30 \mathrm{~kg} / \mathrm{m}^{3}$ to $50 \mathrm{~kg} / \mathrm{m}^{3}$. The $\mathrm{K} 2$ value increased as the density increased, indicating that stiffness increased with density. The $50 \mathrm{~kg} / \mathrm{m}^{3}$ PLON block had the largest $\mathrm{K} 1$ and $\mathrm{K} 2$ values and the maximum stiffness. The $20 \mathrm{~kg} / \mathrm{m}^{3}$ PLON block had the smallest K1 and K2 values and the minimum stiffness. The above results indicated that a sitter would feel the seat as significantly stiffer and has less sense of subsidence when sitting on a higher density PLON cushion.

\subsection{Indentation Force Deflection}

Table 3 summarizes the mean support performance indicators. A one-factor analysis of variance (ANOVA) general linear model procedure was performed to analyze the main effects of PLON blocks with different densities on the support performance indicators. Table 4 summarizes the means of the five factors' values, their coefficients of variation $(\mathrm{COV})$ and their comparisons, performed using the LSD multiple comparisons procedure. The ANOVA results indicated that the main effects of PLON blocks with different densities on the five support performance indicators were statistically different at the $5 \%$ significance level.

Table 3. ANOVA results performed on five factors.

\begin{tabular}{|c|c|c|c|c|c|c|c|c|c|c|}
\hline \multirow{2}{*}{ Source } & \multicolumn{2}{|c|}{$25 \%$ IFD } & \multicolumn{2}{|c|}{$40 \%$ IFD } & \multicolumn{2}{|c|}{$65 \%$ IFD } & \multicolumn{2}{|c|}{ SF } & \multicolumn{2}{|c|}{ IHF } \\
\hline & F Value & $p$ Value & F Value & $p$ Value & F Value & $p$ Value & F Value & $p$ Value & F Value & $p$ Value \\
\hline PLON & 29.53 & $<0.0001$ & 48.00 & $<0.0001$ & 67.07 & $<0.0001$ & 23.71 & $<0.0001$ & 8.08 & 0.0004 \\
\hline
\end{tabular}

Table 4. Mean Support performance indicators Values of the four PLON Densities Evaluated in this Study.

\begin{tabular}{|c|c|c|c|c|c|}
\hline \multirow{2}{*}{ Support Performance Indicators } & \multicolumn{4}{|c|}{ PLON Density $\left(\mathrm{kg} / \mathrm{m}^{3}\right)$} & \multirow{2}{*}{ LSD Values } \\
\hline & $20 \mathrm{~kg} / \mathrm{m}^{3}$ & $30 \mathrm{~kg} / \mathrm{m}^{3}$ & $40 \mathrm{~kg} / \mathrm{m}^{3}$ & $50 \mathrm{~kg} / \mathrm{m}^{3}$ & \\
\hline $25 \%$ IFD & 101.00 (9) C & 119.00 (11) C & 173.37 (21) B & $247.00(22) \mathrm{A}$ & 34.992 \\
\hline $40 \%$ IFD & 173.35 (6) C & 231.18 (9) C & 356.35 (18) B & 498.23 (19) A & 59.827 \\
\hline $65 \%$ IFD & $426.00(7) \mathrm{D}$ & 982.00 (9) C & $1648.72(20) \mathrm{B}$ & 2097.00 (17) A & 253.53 \\
\hline SF & $4.23(3) \mathrm{C}$ & $4.49(24) \mathrm{B}$ & $9.76(22) \mathrm{A}$ & 8.60 (12) A B & 1.3587 \\
\hline IHF & $5.84(21) \mathrm{C}$ & 6.05 (10) BC & $9.68(32) \mathrm{A}$ & 7.88 (15) A B & 1.8337 \\
\hline
\end{tabular}

\subsubsection{The $25 \%$ Indentation Force Deflection (25\% IFD)}

The 25\% Indentation Force Deflection (later referred to as IFD) is known as the force necessary to produce $25 \%$ indentations in the product. The $25 \%$ IFD reflects the tightness and firmness of the cushion in the initial stage of compression. The results of Tables 3 and 4 indicate that there were no significant differences among PLON blocks with densities of $20 \mathrm{~kg} / \mathrm{m}^{3}$ and $30 \mathrm{~kg} / \mathrm{m}^{3}$, but there were significant differences among PLON blocks with densities of $30 \mathrm{~kg} / \mathrm{m}^{3}, 40 \mathrm{~kg} / \mathrm{m}^{3}$ and $50 \mathrm{~kg} / \mathrm{m}^{3}$. The $25 \%$ IFD was sensitive to density changes when the density was higher than $30 \mathrm{~kg} / \mathrm{m}^{3}$ and it significantly increased with density. According to ASTM-D3574-B1, the cushion's supporting ability would be improved after an increase of the $25 \%$ IFD value. When the $25 \%$ IFD value was $53-80 \mathrm{~N}$, it 
can be used in interior cushion because it indicated that the cushion was very soft. When the $25 \%$ IFD value was 80-106 N, the cushion was soft and can only supply a weaker supporting capacity. When the 25\% IFD value was 106-132 N, the cushion had a strong supporting capacity. When the 25\% IFD value was $132-159 \mathrm{~N}$, the cushion had a stronger supporting capacity. The $25 \%$ IFD of the $20 \mathrm{~kg} / \mathrm{m}^{3}$ PLON block was between $80-106 \mathrm{~N}$, indicating that it can only supply a weaker supporting capacity. The $25 \%$ IFD of the $30 \mathrm{~kg} / \mathrm{m}^{3}$ PLON block was between 106-132 N, indicating it had a strong supporting capacity. The $25 \%$ IFD of the $40 \mathrm{~kg} / \mathrm{m}^{3}$ and $50 \mathrm{~kg} / \mathrm{m}^{3}$ PLON blocks was higher than $159 \mathrm{~N}$, and had a very strong supporting capacity.

\subsubsection{The $40 \%$ Indentation Force Deflection (25\% IFD)}

The $40 \%$ IFD refers to the required force that is necessary to produce $40 \%$ indentations in the thickness direction. The greater the force required, the harder the cushion will be. For the $40 \%$ IFD, Tables 3 and 4 show that significant differences existed in PLON blocks with densities of $30 \mathrm{~kg} / \mathrm{m}^{3}, 40 \mathrm{~kg} / \mathrm{m}^{3}$ and $50 \mathrm{~kg} / \mathrm{m}^{3}$. The $40 \%$ IFD was sensitive to density changes when the density was higher than $30 \mathrm{~kg} / \mathrm{m}^{3}$ and it significantly increases with density.

\subsubsection{The $65 \%$ Indentation Force Deflection (25\% IFD)}

The $65 \%$ IFD represents the force needed to produce $65 \%$ indentations in the thickness direction. The results in Tables 3 and 4 also showed that, for $65 \%$ IFD, the differences among PLON blocks with densities of $20 \mathrm{~kg} / \mathrm{m}^{3}, 30 \mathrm{~kg} / \mathrm{m}^{3}, 40 \mathrm{~kg} / \mathrm{m}^{3}$ and $50 \mathrm{~kg} / \mathrm{m}^{3}$ are remarkable. The $65 \%$ IFD was sensitive to density changes and it significantly increases with density.

\subsubsection{Support Factor (Later Referred to as SF)}

Support Factor (later referred to as SF) is also known as a comfort factor. The higher the support factor is, the higher the support ability of the FPF seat surface will be. SF is calculated by Formula 1. Overall, under different IFDs, there were distinct differences among PLON blocks in densities of $20 \mathrm{~kg} / \mathrm{m}^{3}, 30 \mathrm{~kg} / \mathrm{m}^{3}, 40 \mathrm{~kg} / \mathrm{m}^{3}$ and $50 \mathrm{~kg} / \mathrm{m}^{3}$. SF was sensitive to density changes and it significantly increases with density. According to ASTM-D3574-B1, the supporting capacity changes in accordance with the SF value. According to Tables 3 and 4, density had a significant impact on the supporting capacity of the soft PLON blocks. The PLON blocks with a density of $50 \mathrm{~kg} / \mathrm{m}^{3}$ and $40 \mathrm{~kg} / \mathrm{m}^{3} \mathrm{had}$ the largest SF and the strongest support ability, followed by PLON blocks with densities of $30 \mathrm{~kg} / \mathrm{m}^{3}$ and $20 \mathrm{~kg} / \mathrm{m}^{3}$. The supporting capacity of PLON blocks with densities of $50 \mathrm{~kg} / \mathrm{m}^{3}$ and $30 \mathrm{~kg} / \mathrm{m}^{3}$ was equivalent. The SF of the $40 \mathrm{~kg} / \mathrm{m}^{3}$ PLON block was $117 \%$ higher than that of the $30 \mathrm{~kg} / \mathrm{m}^{3}$ PLON block, indicating that the supporting capacity increased as the density of green velvet increased. According to ASTM-D3574-B1, the seating surface was considered comfortable when the SF value was more than 2.8 though the seating surface was considered uncomfortable and prone to bottoming when the SF value was less than 2.8. According to the data in Table 4, the SF values of PLON were all significantly higher than 2.8, indicating that PLON had excellent supporting properties and were considered comfortable.

$$
\mathrm{SF}=\frac{65 \% \mathrm{IFD}}{25 \% \mathrm{IFD}}
$$

\subsubsection{Initial Hardness Factor (Later Referred to as IHF)}

The Initial Hardness Factor (later referred to as IHF) was used to measure the initial surface touch of the FPF seat surface. The higher the initial hardness factor value is, the softer the seat surface will be. IHF is calculated by formula (2). The ANOVA results in Tables 3 and 4 indicate that there were significant differences among $50 \mathrm{~kg} / \mathrm{m}^{3}, 40 \mathrm{~kg} / \mathrm{m}^{3}$ PLON blocks and $30 \mathrm{~kg} / \mathrm{m}^{3}, 20 \mathrm{~kg} / \mathrm{m}^{3}$ PLON blocks. There were no significant differences between $50 \mathrm{~kg} / \mathrm{m}^{3}$ and $40 \mathrm{~kg} / \mathrm{m}^{3}$ PLON blocks, $20 \mathrm{~kg} / \mathrm{m}^{3}$ and $30 \mathrm{~kg} / \mathrm{m}^{3}$ PLON blocks. 
According to ASTM-D3574-B1, the softness increases and decreases along with the IHF value. According to the data in Tables 3 and 4 , the density had a significant effect on the PLON material's softness. The PLON that blocked with a density of $40 \mathrm{~kg} / \mathrm{m}^{3}$ had the largest IHF value and the highest softness. The $50 \mathrm{~kg} / \mathrm{m}^{3}$ and $40 \mathrm{~kg} / \mathrm{m}^{3}$ PLON blocks had an equivalent softness. The $30 \mathrm{~kg} / \mathrm{m}^{3}$ and $20 \mathrm{~kg} / \mathrm{m}^{3}$ PLON samples had the equivalent softness.

$$
\mathrm{IHF}=\frac{25 \% \mathrm{IFD}}{5 \% \text { IFD }} .
$$

There was no significant difference between P20 and P30 for IHF values, but the difference between P20 and P30 for SF value is significant. It was indicated that P30 had equivalent softness and higher supporting capacity compared with P20. There was no significant difference between P50 and P40 for SF values and IHF values, indicating that the supporting ability and softness of P50 and P40 was equivalent. Above all, in practical applications, the PLON materials of $30 \mathrm{~kg} / \mathrm{m}^{3}$ should be preferentially selected for the softer type of mattress and $40 \mathrm{~kg} / \mathrm{m}^{3}$ should be preferentially selected for the harder type of mattress.

\section{Conclusions}

An indentation hardness test and the related mechanical performance test analysis were carried out to explore the compression deformation characteristics, support performance of the PLON blocks and effective application of PLON in mattress products. The main conclusions are drawn as follows:

(1) The $\mathrm{K} 1$ value was more sensitive to density changes that range from $30 \mathrm{~kg} / \mathrm{m}^{3}$ to $50 \mathrm{~kg} / \mathrm{m}^{3}$ while the $\mathrm{K} 2$ value was sensitive to density changes that range from $20 \mathrm{~kg} / \mathrm{m}^{3}$ to $50 \mathrm{~kg} / \mathrm{m}^{3}$. K1 and K2 values increase along with the density, indicating that stiffness is in accordance with density. The above results indicate that a sitter would feel that the seat is significantly stiffer and have less of a sense of subsidence when sitting on a higher density PLON cushion;

(2) The $25 \%$ IFD, $40 \%$ IFD, 65\% IFD, SF and IHF were sensitive to density changes and significantly increase with density. The $20 \mathrm{~kg} / \mathrm{m}^{3}$ PLON block can only supply a weaker supporting capacity. The $30 \mathrm{~kg} / \mathrm{m}^{3}$ PLON block had a strong supporting capacity. The $40 \mathrm{~kg} / \mathrm{m}^{3}$ and $50 \mathrm{~kg} / \mathrm{m}^{3}$ PLON blocks had a very strong supporting capacity. The PLON that was blocked with a density of $50 \mathrm{~kg} / \mathrm{m}^{3}$ and $40 \mathrm{~kg} / \mathrm{m}^{3}$ had the largest SF value and strongest support ability. The $20 \mathrm{~kg} / \mathrm{m}^{3}$ PLON block had the smallest SF value. The SF values of PLON were all significantly higher than 2.8, indicating that PLON blocks had excellent supporting properties and were considered comfortable. Density also had a significant effect on the PLON material's IHF value. The PLON that was blocked with a density of $40 \mathrm{~kg} / \mathrm{m}^{3}$ had the largest IHF value and the highest softness. The $50 \mathrm{~kg} / \mathrm{m}^{3}$ and $40 \mathrm{~kg} / \mathrm{m}^{3}$ PLON samples had equivalent softness. The $30 \mathrm{~kg} / \mathrm{m}^{3}$ and $20 \mathrm{~kg} / \mathrm{m}^{3}$ PLON samples had equivalent softness;

(3) P30 had equivalent softness but a higher supporting capacity compared with P20. P40 had equivalent softness and supporting capacity compared with P50. In practical applications, PLON materials of $30 \mathrm{~kg} / \mathrm{m}^{3}$ should be preferentially selected for the softer type of mattress and $40 \mathrm{~kg} / \mathrm{m}^{3}$ should be preferentially selected for the harder type of mattress.

Author Contributions: Conceptualization, Methodology, Validation, Resources, Data Curation, Writing-Original Draft Preparation, Data Analysis, Q.L.; Investigation, T.L.; Resources, W.L., H.F.; Writing-Review and Editing, Supervision, Y.G. and W.X. All authors have read and agreed to the published version of the manuscript.

Funding: This research was funded by Application Research of Jinquan Green Velvet-PLON Fiber Material in Mattress; International Cooperation Joint Laboratory for Production, Education, Research and Application of Ecological Health Care on Home Furnishing.

Institutional Review Board Statement: Not applicable. 
Informed Consent Statement: Not applicable.

Data Availability Statement: Not applicable.

Conflicts of Interest: The authors declare no conflict of interest.

\section{References}

1. Chao, Y.; Shen, L.M.; Liu, M.P. Mechanical characteristic and analytical model of novel air spring for ergonomic mattress. Mech. Ind. 2021, 22, 37. [CrossRef]

2. Li, X.X.; Zhou, B.; Shen, L.M.; Wu, Z.H. Exploring the effect of mattress cushion materials on human-mattress interface temperatures, pre-sleep thermal state and sleep quality. Indoor Built Environ. 2020, 30, 650-664. [CrossRef]

3. Li, X.; Shen, L.; Califano, R. The comparative study of thermal comfort and sleep quality for innovative designed mattress in hot weather. Sci. Technol. Built Environ. 2020, 26, 643-657. [CrossRef]

4. Zhang, K.T.; Weng, B.B.; Cheng, D.; Guo, Y.; Chen, T.; Wang, L.; Wang, C.X.; Xu, R.M.; Chen, Y.X. Influence of chemical treatment and drying method on the properties of cellulose fibers of luffa sponge. Int. J. Biol. Macromol. 2021, 180, 112-120. [CrossRef] [PubMed]

5. Chen, Y.; Su, N.; Zhang, K.; Zhu, S.; Zhu, Z.; Qin, W.; Yang, Y.; Shi, Y.; Fan, S.; Wang, Z.; et al. Effect of fiber surface treatment on structure, moisture absorption and mechanical properties of luffa sponge fiber bundles. Ind. Crops Prod. 2018, 123, 341-352. [CrossRef]

6. Low, F.-Z.; Chua, M.C.-H.; Lim, P.-Y.; Yeow, C.-H. Effects of Mattress Material on Body Pressure Profiles in Different Sleeping Postures. J. Chiropr. Med. 2017, 16, 1-9. [CrossRef]

7. Cheng, D.; Weng, B.; Chen, Y.; Zhai, S.; Wang, C.; Xu, R.; Guo, J.; Lv, Y.; Shi, L.; Guo, Y. Characterization of potential cellulose fiber from Luffa vine: A study on physicochemical and structural properties. Int. J. Biol. Macromol. 2020, 164, 2247-2257. [CrossRef] [PubMed]

8. Kaewtatip, K.; Thongmee, J. Studies on the structure and properties of thermoplastic starch/luffa fiber composites. Mater. Des. 2012, 40, 314-318. [CrossRef]

9. Chen, Y.; Su, N.; Zhang, K.; Zhu, S.; Zhao, L.; Fang, F.; Ren, L.; Guo, Y. In-Depth Analysis of the Structure and Properties of Two Varieties of Natural Luffa Sponge Fibers. Materials 2017, 10, 479. [CrossRef] [PubMed]

10. Kim, K.-Y.; Doh, S.J.; Im, J.N.; Jeong, W.Y.; An, H.J.; Lim, D.Y. Effects of binder fibers and bonding processes on PET hollow fiber nonwovens for automotive cushion materials. Fibers Polym. 2013, 14, 639-646. [CrossRef]

11. Kim, K.-Y.; Doh, S.J.; Im, J.N.; Jeong, W.Y.; An, H.J.; Lim, D.Y. Preparation of Textile Nonwoven Foams Using Elastomeric Binder Fibers for Automotive Cushioning Materials. Sen'i Gakkaishi 2013, 69, 27-33. [CrossRef]

12. Demirel, S.; Tuna, B.E. Constant-Fatigue Performance of Different Polyurethane Foams for Sitting Purposes. Kast. Univ. J. For. Fac. 2019, 19, 225-234. [CrossRef]

13. Demirel, S.; Tuna, B.E. Evaluation of the cyclic fatigue performance of polyurethane foam in different density and category. Polym. Test. 2019, 76, 146-153. [CrossRef]

14. Hu, L.; Tor, O.; Shen, L.; Zhang, J.; Quin, F.; Yu, X. Cushioning capability analysis of seat foundations considering the sitter's anthropometric dimensions. BioResources 2020, 15, 7992-8007. [CrossRef]

15. Xu, W.; Cheng, L.L.; Yang, G.Q.; Fang, L.; Yu, N.; Wang, J.Q.; Huang, Q.T. Analysis of the Influence of Sponge Density on the Comfort of Sofa Cushion. Furniture 2018, 39, 17-21.

16. Huang, L. Research on Indentation Hardness and Supporting Performance of Elastic Material of Sofa Seat. Master's Thesis, Zhejiang Agriculture and Forestry University, Hangzhou, China, 2018.

17. Yu, C.S.; Shen, L.M.; Zhao, H. The effect of mattress pad material and structure on its comprehensive rigidity. Furniture 2019, 40, 90-93.

18. Chen, Y.; Zhang, K.; Guo, Y.; Yuan, F.; Zhu, Z.; Weng, B.; Dai, L.; Wu, S.; Su, N. Compression Properties of Two Novel Natural Luffa Mattress Filling Materials. J. Nat. Fibers 2019, 18, 594-606. [CrossRef]

19. Gu, Y.T.; Wu, Z.H.; Zhang, J.L. Load-deflection behavior of rattan chair seats. Wood Fiber Sci. 2016, 48, 13-24.

20. Zhu, Z.; Buck, D.; Guo, X.; Cao, P. High-quality and high-efficiency machining of stone-plastic composite with diamond helical cutters. J. Manuf. Process. 2020, 58, 914-922. [CrossRef]

21. Zhu, Z.; Buck, D.; Cao, P.; Guo, X.; Wang, J. Assessment of Cutting Forces and Temperature in Tapered Milling of Stone-Plastic Composite Using Response Surface Methodology. JOM 2020, 72, 3917-3925. [CrossRef]

22. Zhu, Z.; Buck, D.; Guo, X.; Cao, P.; Wang, J. Cutting performance in the helical milling of stone-plastic composite with diamond tools. CIRP J. Manuf. Sci. Technol. 2020, 31, 119-129. [CrossRef]

23. ASTM D3574-17. Standard Methods of Testing Flexible Cellular Materials-Slab, Bonded and Molded Urethane Foams; ASTM International: West Conshohocken, PA, USA, 2017.

24. Chen, B.Q.; Guan, H.Y. Application of loofah cushion filling material under the utilization of plant fiber resources. Furniture 2021, $42,16-20,35$.

25. Gu, H.W. Basic Research and Optimal Design of Palm Fiber Elastic Material. Master's Thesis, Jinan University, Guangzhou, China, 2015. 